\title{
SEX DIFFERENCES IN THE CONGENITAL ANOMALIES: A HOSPITAL BASED CROSS SECTIONAL STUDY
}

\author{
Nivedita Prashar1, Neha Kachroo², Shashi Gupta33, Bawa Ram Bhagat4, Amita Gupta5, Gopal Sharma6, Preeti Sharma ${ }^{7}$ \\ ${ }_{1}^{1}$ Medical Officer, Department of Obstetrics and Gynaecology, SMGS Hospital. \\ ${ }^{2}$ Senior Resident, Department of Obstetrics and Gynaecology, Lal Bahadur Shastri Hospital, Delhi. \\ 3 Professor and HOD, Department of Obstetrics and Gynaecology, SMGS Hospital. \\ ${ }^{4}$ Consultant, Department of Obstetrics and Gynaecology, SMGS Hospital. \\ ${ }^{5}$ Consultant, Department of Obstetrics and Gynaecology, SMGS Hospital. \\ ${ }^{6}$ Senior Resident, Department of Surgery, GMC, Jammu. \\ 7 Post Graduate, Department of Obstetrics and Gynaecology, SMGS Hospital.
}

ABSTRACT
BACKGROUND
The present study was conducted with an aim to study the sex differences in various congenital anomalies, overall and by
subtype.

\section{MATERIAL AND METHOD}

This cross sectional study was carried out in the Department of Obstetrics and Gynaecology of SMGS Hospital, GMC Jammu during the period of one year from October 2012 to September 2013. All mothers with congenital anomalies proven on antenatal ultrasonography and those mothers having no antenatal record, but after delivery examination of baby revealed anomaly were included. Neonatal and maternal characteristics were recorded.

\section{RESULTS}

There was slightly higher frequency of congenital anomalies among females (1.90\%) as compared to males (1.69\%), although the difference is not statistically significant, $p$ value being 0.318 . Central nervous system anomalies were more common in females $(58.82 \%)$ as compared to males $(39.57 \%)$, frequency of urinary system anomalies were more in males $(63.46 \%)$ as compared to females (34.61\%). No significant difference in relation to sex was observed in musculoskeletal, gastrointestinal and cardiovascular systems. Genital system anomalies, cleft lip/palate and skin anomalies were present in males only.

\section{CONCLUSION}

Survey of congenital anomalies is important to know the prevalence, causes, associated risk factors, reasons for sex differences overall and by subtype and ultimately to reduce the occurrence of major anomalies.

\section{KEYWORDS}

Congenital, Anomaly, Incidence, Sex.

HOW TO CITE THIS ARTICLE: Prashar N, Kachroo N, Gupta S, et al. Sex differences in the congenital anomalies: a hospital based cross sectional study. J. Evolution Med. Dent. Sci. 2016;5(38):2349-2352, DOI: 10.14260/jemds/2016/545

\section{INTRODUCTION}

A congenital anomaly is an abnormality of structure, functions or body metabolism that is present at birth (even if not diagnosed until later in life) and results in physical or mental disability or is fatal. ${ }^{1}$ WHO documented in 1972 that the term congenital malformation should be confined to structural defects at birth and term congenital anomaly being used to include all biochemical, structural and functional disorders present at birth. ${ }^{2}$ Alternatively, it may be defined as a permanent anatomical, histological and biochemical defect which the individual cannot repair through growth and development. ${ }^{3}$ The birth of an infant with major malformations, whether diagnosed antenatally or not evokes an emotional parental response. ${ }^{4}$ Parents require counselling on learning of existence of anomalies in their babies, as it is a state of mental shock for them. Congenital anomalies contribute a significant proportion of infant mortality and

Financial or Other, Competing Interest: None.

Submission 28-03-2016, Peer Review 23-04-2016,

Acceptance 29-04-2016, Published 12-05-2016.

Corresponding Author:

Dr. Nivedita Prashar

Medical Enclave, Quarter No. D5,

Bakshi Nagar, Jammu-180001,

Jammu Kashmir.

E-mail: niveditaprashar@gmail.com

DOI: $10.14260 /$ jemds $/ 2016 / 545$ morbidity as well as foetal mortality. Congenital anomalies account for $8-12 \%$ of perinatal deaths and $13-16 \%$ of neonatal deaths in India.5,6 In general, we cannot measure the incidence of congenital anomalies due to the prenatal loss of foetuses such as blighted ova, miscarriages and ectopic pregnancies. ${ }^{7}$ Various sources estimate the prevalence of congenital anomalies to be in the range of 1-3\% of all live born infants and considerably higher for infants that are still born or spontaneously aborted. $8,9,10$ This rate increases to $5-6 \%$ when the ascertainment period is extended to the age of 5-6 years. ${ }^{8,10}$

In the early part of $19^{\text {th }}$ century, the percentage of deaths from congenital anomalies was relatively low. This was because preventive medicine, immunology and antibiotics were not in usage. Now the number of deaths from infections, metabolic and endocrinal disorders has decreased and so birth defects as a cause of perinatal mortality have come to the forefront. ${ }^{11}$ It was also observed that better maternal care and improved standards of living have very little effect on the overall frequency of congenital malformations. ${ }^{12,13}$

In spite of increasing frequency of congenital anomalies, the underlying cause for most remains obscure. It has been estimated that around $15-25 \%$ are due to recognized genetic conditions (chromosome and single gene causes), 8-12\% are due to environmental conditions (Maternal related conditions, drug or chemical exposure) and $20-25 \%$ are due to 
multifactorial inheritance. ${ }^{14}$ The majority of congenital anomalies (40-60\%) have unexplained causes.

The actual mechanism of malformation is largely unknown, but may involve various errors in embryonic cell proliferation, differentiation, migration and programmed death as well as cell-to-cell communication. Studies have found that the frequency of occurrence of certain congenital malformation depend on the sex of the child. Congenital anomalies are now aetiologically considered as the outcome of intricate interaction between host and environment. Limited data is available regarding the sex distribution of congenital anomalies and their subtypes. The present study was conducted with aims to study the sex difference in various congenital anomalies, overall and by subtype in our region, so that it can act as a database for further aetiological research.

\section{MATERIAL AND METHODS}

This cross sectional observational study was carried out in the Department of Obstetrics and Gynaecology of SMGS Hospital, Government Medical College, Jammu, during the period of one year from October 2012 to September 2013. All women with congenital anomalies proven on antenatal ultrasonography and those women having no antenatal record, but after delivery/abortion examination of baby revealed anomaly were included in the study. Once the diagnosis of major malformation (Incompatible with life) was made in the ultrasonography, those pregnancies were terminated by any method of induction of labour. After delivery, meticulous examination of baby was done. System wise distribution of the anomalies was performed. Neonatal characteristics including live birth or still birth, Apgar score, sex were recorded. Observations were tabulated and analysed as percentages deemed appropriate for qualitative variables.

\section{RESULTS}

During this one-year study, a total of 15447 new-borns were delivered to 15143 mothers; among whom 8164 were males, 7274 were females and 9 were with ambiguous genitalia. There were 14850 singleton births, 282 twin births and 11 triple births. Out of 15447 newborns, 285 were having congenital anomalies accounting to an incidence of $1.85 \%$. There was slightly higher frequency of congenital anomalies in females (1.90\%) as compared to males (1.69\%). However, the difference is not statistically significant, the $\mathrm{p}$ value being 0.318 ( $\mathrm{p}$ value $<0.05$ is considered significant). Hydrocephalus, meningocele and anencephaly were the most common central nervous system anomalies. They constituted $35.83 \%, 21.39 \%$ and $20.85 \%$ respectively of all CNS anomalies. CNS anomalies were more common in females $(58.82 \%)$ as compared to males (39.57\%) [p value=0.007] Hydronephrosis was the commonest malformation in urinary system followed by cystic kidneys accounting for $57.69 \%$ and $17.30 \%$ of urinary system anomalies respectively. Frequency of urinary system anomalies were more in males $(63.46 \%)$ as compared to females (34.61\%) [p value-0.035]. Club foot was the most common anomaly in musculoskeletal system and accounted for $28.57 \%$ of all anomalies of this system followed by limb and spine deformities contributing to $18.36 \%$ each. These anomalies were almost equally present between male and female ( $48.97 \mathrm{v} / \mathrm{s} 46.94 \%$ ) and $\mathrm{p}$ value is 0.88 . Gut atresia was the commonest anomaly (constituting 37.04\%) in gastrointestinal system. No significant difference in relation to sex was observed ( $\mathrm{p}$ value $=0.531$ ). Cardiomegaly and septal defects were common anomalies in cardiovascular system. No difference in relation to sex was observed ( $p$ value $=1$ ). Nine newborns were having ambiguous genitalia. Rest all genital system anomalies were present in males. Cleft lip was present in four newborns and cleft lip with cleft palate also in four newborns. No sex difference was observed. No significant sex difference was observed in relation to anomalies of eye, ear, face, neck and respiratory system. All skin anomalies were seen in males. Down syndrome was present in two male newborns. Table 1 shows the distribution of anomalies of various systems in relation to sex of the newborn.

\begin{tabular}{|c|c|c|c|c|c|c|}
\hline \multirow{2}{*}{$\begin{array}{c}\text { Type of } \\
\text { Anomaly }\end{array}$} & $\begin{array}{c}\text { Male } \\
\text { No. } \\
(\%)\end{array}$ & $\begin{array}{c}\text { Female } \\
\text { No. } \\
(\%)\end{array}$ & $\begin{array}{c}\text { Ambi- } \\
\text { guous } \\
\text { No. (\%) }\end{array}$ & $\begin{array}{c}\text { Total } \\
\text { No. }\end{array}$ & $\begin{array}{c}\text { Chi- } \\
\text { Square }\end{array}$ & $\begin{array}{c}\text { P- } \\
\text { value }\end{array}$ \\
\hline $\begin{array}{c}\text { Central } \\
\text { Nervous } \\
\text { system }\end{array}$ & $\begin{array}{c}74 \\
(39.57)\end{array}$ & $\begin{array}{c}110 \\
(58.82)\end{array}$ & $\begin{array}{c}3 \\
(1.604)\end{array}$ & 187 & 7.043 & $\begin{array}{c}0.007 \\
(* *)\end{array}$ \\
\hline $\begin{array}{c}\text { Urinary } \\
\text { system }\end{array}$ & $\begin{array}{c}33 \\
(63.46)\end{array}$ & $\begin{array}{c}18 \\
(34.61)\end{array}$ & $\begin{array}{c}1 \\
(1.92)\end{array}$ & 52 & 4.412 & $\begin{array}{c}0.035 \\
(*)\end{array}$ \\
\hline $\begin{array}{c}\text { Musculo- } \\
\text { skeletal } \\
\text { system }\end{array}$ & $\begin{array}{c}24 \\
(48.97)\end{array}$ & $\begin{array}{c}23 \\
(46.94)\end{array}$ & $\begin{array}{c}2 \\
(4.08)\end{array}$ & 49 & 0.021 & 0.88 \\
\hline $\begin{array}{c}\text { GIT } \\
\text { system }\end{array}$ & $\begin{array}{c}13 \\
(48.15)\end{array}$ & $\begin{array}{c}10 \\
(37.03)\end{array}$ & $\begin{array}{c}4 \\
(14.81)\end{array}$ & 27 & 0.391 & 0.531 \\
\hline $\begin{array}{c}\text { Cardio- } \\
\text { vascular } \\
\text { system }\end{array}$ & $\begin{array}{c}11 \\
(50)\end{array}$ & $\begin{array}{c}11 \\
(50)\end{array}$ & 0 & 22 & 0 & 1 \\
\hline $\begin{array}{c}\text { Genital } \\
\text { system }\end{array}$ & $\begin{array}{c}4 \\
(30.76)\end{array}$ & 0 & $\begin{array}{c}9 \\
(69.23)\end{array}$ & 13 & 4 & 0.045 \\
\hline $\begin{array}{c}\text { Cleft lip/ } \\
\text { palate }\end{array}$ & $\begin{array}{c}4 \\
(50)\end{array}$ & $\begin{array}{c}4 \\
(50)\end{array}$ & 0 & 8 & 0 & 1 \\
\hline $\begin{array}{c}\text { Eye, ear, } \\
\text { face and } \\
\text { neck }\end{array}$ & $\begin{array}{c}1 \\
(33.33)\end{array}$ & $\begin{array}{c}2 \\
(66.67)\end{array}$ & 0 & 3 & 0.33 & 0.563 \\
\hline $\begin{array}{c}\text { Respiratory } \\
\text { system }\end{array}$ & $\begin{array}{c}2 \\
(50)\end{array}$ & $\begin{array}{c}2 \\
(50)\end{array}$ & 0 & 4 & 0 & 1 \\
\hline Skin & $\begin{array}{c}4 \\
(100)\end{array}$ & 0 & 0 & 4 & 4 & 0.045 \\
$\left({ }^{*}\right)$
\end{tabular}

*Significant

**Highly Significant

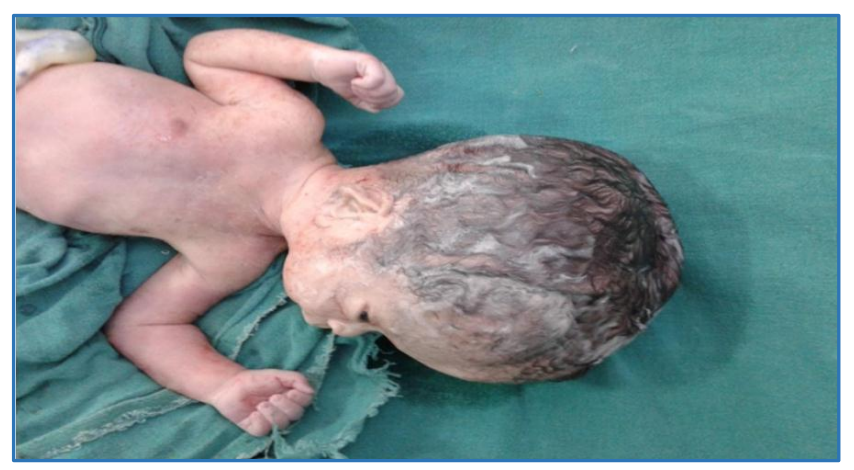

Fig. 1: Hydrocephalus 


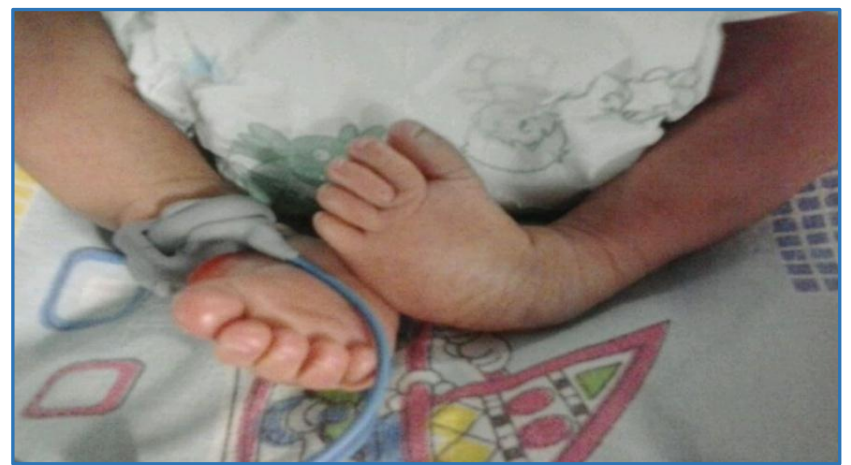

Fig. 2: Clubfeet

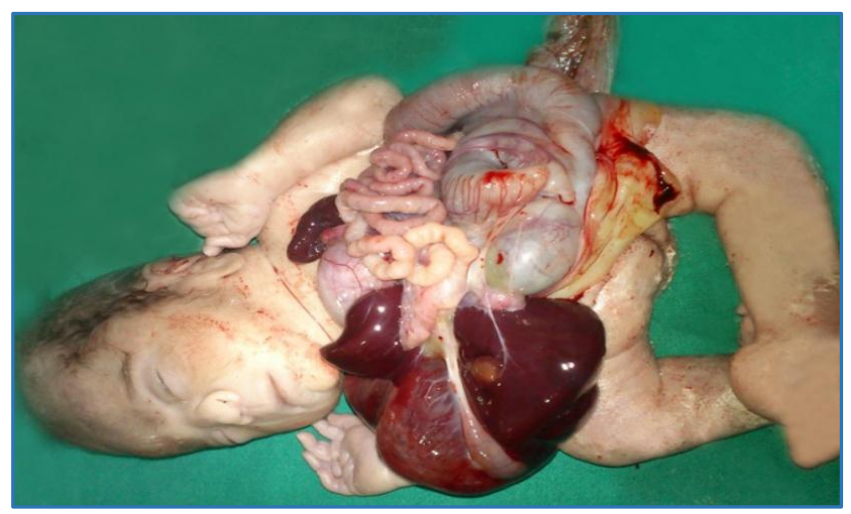

Fig. 3: Gastroschisis

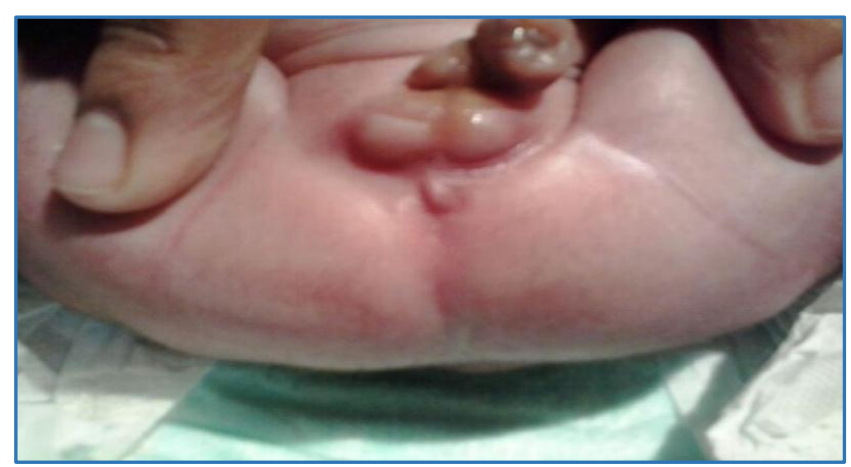

Fig. 4: Imperforate Anus

\section{DISCUSSION}

In the present study the overall incidence of congenital anomalies was $1.85 \%$, which was almost comparable with other studies by Khan AA (1965). ${ }^{15}$, Patel ZM et al (2005).16, Rad Abdi et al (2007).17, Taksande et al (2010).18, El Koumi et al (2013). ${ }^{19}$ There was higher incidence of congenital anomalies in female $(1.90 \%)$ as compared to the males (1.69\%). Similar results were shown by Rad Abdi et al (2007). ${ }^{17}$ Shawky et al (2001). ${ }^{20}$ also observed M:F ratio of anomalies to be $0.6: 1$.

With regard to individual malformation, hydrocephalus was the commonest anomaly in central nervous system constituting $35.83 \%$ of all anomalies of CNS. Similar results were shown in other studies by Shawky and Sadik (2011).21 and Mohammed et al (2011).22 Hydronephrosis was the most common anomaly in urinary system. Results are in consonance with other studies.(21,22) In musculoskeletal system, club foot was the most common commonly constituting $28.57 \%$ of these anomalies. These results are comparable to other studies. $(18,22)$
In gastrointestinal system, gut atresia and omphalocele constituted the largest group accounting for $48.15 \%$ of all GI anomalies. Similar results were obtained by Padma et al (2011). ${ }^{23}$ In CVS, cardiomegaly and septal defects were present in $18.18 \%$ and $13.63 \%$ of all CVS anomalies. Shawky and Sadik (2011). ${ }^{21}$ also showed similar results. In genital system, nine cases of ambiguous genitalia were present. Ambiguous genitalia were present in three cases in study by Taksande et al (2010). ${ }^{18}$ Cleft lip/cleft palate constituted $2.12 \%$ of total anomalies in the present study. Mohammed et al (2011). ${ }^{22}$ reported anomalies of cleft lip/palate to be $4.57 \%$. Anomalies of eye, ear, face and neck constituted $0.8 \%$ of total anomalies. Anomalies of respiratory system and skin constituted $1.06 \%$ of all anomalies each. $1.59 \%$ of all anomalies were unclassified. CNS malformations were more common in females as compared to males $(58.82 \% \mathrm{v} / \mathrm{s}$ $39.57 \%$ ). Female predominance was seen in hydrocephalus (38 females), anencephaly (29 females) and spina bifida ( 9 females) as compared to 29, 9 and 6 males respectively. Tokuhata et al (1973). ${ }^{24}$ also observed similar results. Urinary system anomalies were more common in males $(63.46 \%)$ as compared to females (34.61\%) in the present study.

Lary and Paulozzi (2001).25 also observed urinary defects to be $62 \%$ more prevalent among males as compared to females. In the present study, male predominance was seen in hydronephrosis (20 males v/s 10 females). Lary and Paulozzi (2001). ${ }^{25}$ also reported defects of sex organs to be 8.5 times more prevalent among males as shown in our study.

In present study, musculoskeletal anomalies were equally observed among males and females, although significant heterogeneity between subtypes was present. Male predominance for club foot was seen. Miedzybrodzka (2003). ${ }^{26}$ also observed similar results. In present study, GI anomalies were slightly more in males with significant sex difference in relation to gut atresia was seen. Singh et al (2011) 27 observed CVS anomalies to be equally present in males and females as in our study. In present study cleft lip/palate, anomalies of respiratory system, eye, ear, face and neck and skin were almost equally observed among males and females.

\section{CONCLUSION}

Congenital anomalies continue to be an important cause of mortality and morbidity of infants and children, especially in developing countries. Survey of congenital anomalies must be done in every country and even in different regions of same country to provide prevalence of congenital anomalies, pattern, identify causes and associated risk factors and ultimately to prevent or reduce the occurrence of major anomalies. More research is needed to determine the factors underlying the various types of congenital malformation and reasons for sex differences in various anomalies overall and by subtype as certain anomalies are more common in one sex as compared to other.

\section{REFERENCES}

1. March of dimes resource center. Birth defects 1998. Available from: www.modimes.org.

2. Park K. Congenital malformations. In: Park's textbook of preventive and social medicine1997;15 th $\mathrm{ed}: 379-80$. 
3. Sharma B, Bajpai PC, Sharma NC. Some observations on congenital malformations. Indian J Paediatr 1972;39(296):286-92.

4. Grover N. Congenital malformations in Shimla. Indian J Paediatr 2000;67(4):249-51.

5. Agarwal SS, Singh U, Singh PS, et al. Prevalence and spectrum of congenital malformations in a prospective study at a teaching hospital. Indian J Med Res 1991;94:413-19.

6. Bhat BV, Ravikumara M. Perinatal mortality in IndiaNeed for introspection. Indian J Matern Child Health 1996; 7:31-3.

7. Andrew EC. Birth defects are preventable. Int J Med Sci 2005;2(3):91-2.

8. De Santis M, Straface G, Carducci B, et al. Risk of druginduced congenital defects. Eur J Obstet Gynaecol Reprod Biol 2004;117(1):10-9.

9. Kalter H. Teratology in the $20^{\text {th }}$ century: environmental causes of congenital malformations in humans and how they were established. Neurotoxicol Teratol 2003;25(2):131-282.

10. Schumacher GH. Teratology in cultural documents and today. Ann Anat 2004;186(5-6):539-46.

11. Gupta S, Gupta P, Soni J. A study on incidence of various systemic congenital malformations and their association with maternal factors. Nat J Med Res 2012;2(1):19-21.

12. Nelson MM, Forfar JG. Congenital malformations at birth. Dev Med Child Neurology 1969;11(1):3-16.

13. Stevenson RE. The genetic basis of human anomalies. In: Stevenson RE, Hall JG and Goodman RM (eds). Human malformation and related anomalies. New York: Oxford university press 1993;1:115.

14. Nelson K, Holmes LB. Malformations due to presumed spontaneous mutations in newborn infants. N Engl J Med 1984;320:19-23.

15. Khan AA. Congenital malformations in African neonates in Nairobi. J Trop Med Hyg 1965;68(11):272-74.

16. Patel ZM, Adhia RA. Birth defects surveillance study. Indian J Paediatr 2005;72(6):489-91.
17. Rad Abdi I, Khoshkalam M, Islamlou HR. The prevalence at birth of overt congenital anomalies in Urmia, Northwestern Iran. Arch Iranian Med 2008;11(2):14851.

18. Taksande A, Vilhekar K, Chaturvedi $\mathrm{P}$, et al. Congenital malformations at birth in central India: a rural medical college hospital-based data. Indian J Hum Genet 2010;16(3):159-63.

19. El-Koumi MA, Al-Banna EA, Lebda I. Pattern of congenital anomalies in newborns: a hospital-based study. Paediatr Rep 2013;5(1):20-3.

20. Shawky RM, El-Sedfy HH, Abo Louz SK, et al. Prevalence of congenital malformations in a thousand consecutive Egyptian liveborn. Egypt J Med Genet 2001;2(1):43-53.

21. Shawky RM, Sadik DI. Congenital malformations prevalent among Egyptian children and associated risk factors. Egyptian J Med Hum Genet 2011;12:69-78.

22. Mohammed YA, Shawky MR, Soliman AS, et al. Chromosomal study in newborn infants with congenital anomalies in assiut university hospital: cross-sectional study. Egyptian J Med Hum Genet 2011;12(1):79-90.

23. Padma S, Ramakrishna D, Jijiya Bai $P$, et al. Pattern of distribution of congenital anomalies in stillborn: a hospital-based prospective study. Int J Pharma Biosc 2011;2(2):604-10.

24. Tokuhata GK, Digon E, Mann L. Prenatal care and obstetric abnormalities experiences of 185000 pennsylvania births. J Chron Dis 1973;26(3):163-85.

25. Lary JM, Paulozzi LJ. Sex differences in the prevalence of human birth defects: a population based study. Teratology 2001;64(5):237-51.

26. Miedzybrodzka Z. Congenital talipes equinovarus (clubfoot): a disorder of the foot but not the hand. J Anat 2003;202(1):37-42.

27. Singh D, Wander GS, Singh RJ. Gender equality in India for children with congenital heart disease: looking for answers. Heart 2011;97(23):1897-8. 